FIU Law Review

Spring 2010

\title{
Regulating Sovereign Wealth Funds in the U.S.: A Primer on SWFs and CFIUS
}

Adam Gutin

Follow this and additional works at: https://ecollections.law.fiu.edu/lawreview

Part of the Other Law Commons

Online ISSN: 2643-7759

Recommended Citation

Adam Gutin, Regulating Sovereign Wealth Funds in the U.S.: A Primer on SWFs and CFIUS, 5 FIU L. Rev. 745 (2010).

DOI: https://dx.doi.org/10.25148/lawrev.5.2.21

This Comment is brought to you for free and open access by eCollections. It has been accepted for inclusion in FIU Law Review by an authorized editor of eCollections. For more information, please contact lisdavis@fiu.edu. 


\title{
Regulating Sovereign Wealth Funds in the U.S.: A Primer on SWFs and CFIUS
}

\author{
Adam Gutin*
}

\section{INTRODUCTION}

Suppose that a government of a foreign country created and operated its own investment fund with the intention of making acquisitions within the United States. Does this pose a threat to U.S. economic security? After all, since its earliest days, the United States has welcomed foreign capital. ${ }^{1}$ President Washington sought Dutch capital to help finance the country's growth, and later Scottish trusts were imperative to railroad construction in the United States. ${ }^{2}$ Arguably, it has been acceptable for foreign companies to own real estate and companies in the United States, so why not allow foreign governments to do the same? For the most part, the United States has thus far accepted such a proposition by allowing foreign governmentowned funds, known as sovereign wealth funds, to invest in U.S. assets such as companies, securities and real estate.

Through a series of legislation and executive orders over the past halfcentury, the United States has crafted a body of law to deal with what at least one economist terms "state capitalism." lators have had to balance protectionist sentiment in portions of the electorate with an economy in need of capital influx. ${ }^{4}$ Policy makers have been forced to pass legislation that takes into consideration national security concerns and ongoing foreign policy issues.

In considering this matter, many questions arise. For example, should foreign ownership of domestic corporations be limited? Are there sectors

* Adam Gutin obtained his Juris Doctor degree from the Florida International University College of Law in May of 2010. He also has a Master of Business Administration, Bachelor of Science in Finance, and a Bachelor of Arts in English from the University of Florida. Adam would like to thank Professor Joëlle Moreno, Professor José Gabilondo, Professor Jerry Markham, Brittney Keck, his family, and friends at the FIU Law Review for their work on the publication.

1 See Thomas E. Crocker, What Banks Need to Know About the Coming Debate Over CFIUS, Foreign Direct Investment, and Sovereign Wealth Funds, 125 BANKING L.J. 457, 461 (2008).

$I d$. ("[F]oreign direct investment is neither new nor necessarily detrimental.").

3 See Gerard Lyons, State Capitalism: The Rise of Sovereign Wealth Funds, 14 L. \& Bus. REv. AM. 179, 183 (2008) ("State Capitalism is the use of government controlled funds to acquire strategic stakes around the world.").

4 See infra Part II.C. 
of the economy that are too sensitive to foreign ownership (i.e., energy, telecommunications, aerospace, defense)? What level of trade barrier is too much? Plus, legislators must be careful, because "the hypocrisy of erecting barriers to foreign investment while demanding open access to developing markets is self-evident." Historically, countries such as China and Russia have not always had interests aligned with the United States. Should sovereign wealth funds from these countries be allowed to invest in the United States? What possible harm could result from allowing them to do so? Should policy makers be concerned that sovereign wealth funds may be used for motives that are not strictly economic? Many sovereign wealth funds are owned and operated by non-democratic nations. ${ }^{6}$ Could such funds "create marketplace chaos, given that their economic and security interests are not always consistent with U.S. policy"? ${ }^{7}$ Could these funds "be used to apply political pressure, manipulate markets, gain access to sensitive technologies, or undermine economic rivals"? ${ }^{8}$ This comment will examine how policy makers have reacted to such questions.

The Committee on Foreign Investment in the United States (CFIUS) is meant to regulate foreign investment in the United States by entities such as sovereign wealth funds (SWFs). In addition, the International Monetary Fund (IMF) and Organisation for Economic Co-operation and Development (OECD) have adopted best practices for sovereign wealth funds. These practices dictate not only how a SWF should behave in making its investments, but also how countries that are recipients of SWF investment should behave. This comment will also examine the CFIUS review process and the best practices adopted by the IMF and OECD.

Section II below discusses the history of SWFs, their behavior recently in the marketplace, as well as concerns over SWFs based on national security and the need for economic stability. Section III then examines the review process CFIUS has created for foreign investment to be made into the United States.

5 The Invasion of the Sovereign Wealth Funds, ECONOMIST, Jan. 17, 2008, available at http://www.economist.com/node/10533866?story_id=10533866.

6 Aaron Lorenzo, Foreign Investment: Vet Sovereign Wealth Funds When Sensitive Sectors Involved, Senate Panel Told, 25 INT'L TRADE REP. (BNA) 911 (2008).

7 Aaron Lorenzo, Foreign Investment: Lawmakers Receive Warnings on Monitoring Sovereign Wealth Funds, 25 INT'L TRADE REP. (BNA) 1338 (2008).

8 Lorenzo, supra note 6. 


\section{BACKGROUND}

\section{A. What Are Sovereign Wealth Funds and Where Did They Come From?}

Until recently, "there [was] no universally accepted definition of [sovereign wealth funds (SWFs)]." However, the International Working Group of Sovereign Wealth Funds (IWG) has defined SWFs as "special purpose investment funds or arrangements, owned by the general government. Created by the general government for macroeconomic purposes, SWFs hold, manage, or administer assets to achieve financial objectives, and employ a set of investment strategies that include investing in foreign financial assets." $"$ The common characteristic among SWFs is that they are owned "by a sovereign nation state rather than a regional or local state entity; not national pension funds and not central banks or authorities that perform roles typical of a central bank."11 An alternative, but not inconsistent definition describes SWFs as "separate pools of international assets owned and managed by governments to achieve a variety of economic and financial objectives." ${ }^{\prime 2}$

Generally, SWFs are created by countries that need to manage surplus reserve funds. ${ }^{13}$ Countries with nonrenewable resources, such as oil or other commodities, take profits from that resource and invest it for future generations, so when the resource runs dry, these countries will not be in poverty. ${ }^{14}$ Sovereign wealth funds "can serve a variety of government ob-

9 Crocker, supra note 1, at 462; see also Lyons, supra note 3, at 184.

10 InT'L WORKIng Group of SOVEREIGN Wealth Funds, SOvereign Wealth Funds: Generally ACCePted Principles AND Practices: "SAntiago Principles" 27 (Oct. 2008), http://www.iwg-swf.org/pubs/eng/santiagoprinciples.pdf [hereinafter Santiago Principles]; see also Simon Willison, Wealth Funds Group Publishes 24-Point Voluntary Principles (Oct. 15, 2008), available at http://www.imf.org/external/pubs/ft/survey/so/2008/NEW101508B.htm.

11 Lyons, supra note 3, at 184.

12 Peter Heyward, Sovereign Wealth Fund Investments in US Financial Institutions: Too Much Or Not Enough?, 27 No. 5 BANKING \& Fin. SERVICES POL'Y REP. 19 (2008) (citing Ted Truman, a Senior Fellow at the Peterson Institute for International Economics).

13 "All countries have foreign exchange reserves (these days, they're typically in dollars, euros, or yen). When a country, by running a current account surplus, accumulates more reserves than it feels it needs for immediate purposes, it can create a sovereign fund to manage those "extra' resources." Simon Johnson, The Rise of Sovereign Wealth Funds, 44 Fin. \& DEV. 56 (2007), available at http://www.imf.org/external/pubs/ft/fandd/2007/09/straight.htm.

14 John L. Walker \& Mark J. Chorazak, Sovereign Wealth Funds: The Evolving Legal and Regulatory Landscape, WASHINGTON LEGAL FoundaTION: CRITICAL LEGAL ISSUES: WORKING PAPER SERIES (2008), available at http://www.wlf.org/publishing/publication_detail.asp?id=2003:

In the early 1950s, Kuwait experienced a surge in oil revenues and sought to plan for the day when its oil wells would run dry. Put simply, the idea was that proceeds in excess of what was needed for its government to function could be transferred into a separate "fund for the future" for investment in areas that were less volatile. 
jectives, such as diversifying revenues to avoid excessive reliance on a nonrenewable commodity export; setting aside reserves against the day when that crucial commodity has become depleted; or managing the potentially disruptive impact on domestic financial markets of large trade surpluses." ${ }^{15}$ In addition, the IMF states that SWFs "help avoid boom-bust cycles in their home countries, and facilitate the saving and transfer across generations of proceeds from fiscal surpluses related to commodity exports and privatizations." 16 Furthermore, SWFs reduce the opportunity costs of reserve holdings as they have a greater focus on returns than the typical central-bank. ${ }^{17}$ Finally, "[i]n recipient countries, sovereign wealth funds can also bring the benefits normally associated with foreign investment such as stimulating business activity and creating jobs." ${ }^{\prime 18}$

According to the IMF:

Five types of sovereign wealth funds can be broadly distinguished based on their main objective:

1) stabilization funds, where the primary objective is to insulate the budget and the economy against commodity (usually oil) price swings;

2) savings funds for future generations, which aim to convert nonrenewable assets into a more diversified portfolio of assets;

3) reserve investment corporations, whose assets are often still counted as reserve assets, and are established to increase the return on reserves;

4) development funds, which typically help fund socioeconomic projects or promote industrial policies that might raise a country's potential output growth; and

5) contingent pension reserve funds, which provide (from sources other than individual pension contributions) for contingent unspecified pension liabilities on the government's balance sheet. ${ }^{19}$

In 2008, sovereign wealth funds' total assets were estimated to range between $\$ 2$ trillion and $\$ 3$ trillion. $^{20}$ Also, as of 2008 , the total collective

15 Heyward, supra note 12, at 19.

16 InT'L MONETARy Fund, IMF InTENSIFIES Work ON SOVEREIGN WeALth Funds (2008), http://www.imf.org/external/pubs/ft/survey/so/2008/POL03408A.htm.

17 Id.

18 OECD, SOVEREIGn WeAlth Funds AND RECIPIENT COUNTRY POLICIES 2 (2008), available at www.oecd.org/dataoecd/34/9/40408735.pdf.

19 INT'L MONETARY FUND, supra note 16.

20 Heyward, supra note 12, at 19. 
size of SWFs "exceeds the total assets currently managed by hedge funds and private equity funds." 21 From 2000 to 2008, "the number of funds . . . doubled ... (from twenty to almost forty now), with over ten established since 2005."22 Rising fuel prices benefited the Middle Eastern countries and enabled their SWFs to grow. ${ }^{23}$

Part 1 below describes the earliest sovereign wealth funds, and Part 2 below discusses China and Russia, two countries that have recently formed their own SWFs.

\section{The Earliest Sovereign Wealth Funds}

Sovereign wealth funds have been around since the 1950s and have remained relatively unnoticed by the general public until recent times. ${ }^{24}$ One of the earliest SWFs was created in 1953 by Kuwait. ${ }^{25}$ The Kuwait Investment Authority "was set up ... with the aim of investing surplus oil revenues to reduce the reliance of Kuwait on its finite oil resource. The State of Kuwait transfers $10 \%$ of oil revenue into the Reserve for Future Generations each year." 26 Notably after thirty-three years of existence, in 1986, statistics indicated that Kuwait's "government revenue from investments exceeded revenues from oil., ${ }^{27}$

The Abu Dhabi Investment Authority (ADIA), created in 1976, holds a similar goal as the Kuwait Investment Authority - "to invest funds on behalf of the Government of the Emirate of Abu Dhabi to make available the necessary financial resources to secure and maintain the future welfare of the Emirate." "28 “T]he Abu Dhabi Investment Authority, set up in 1977, is now the world's largest SWF." ${ }^{29}$ As of April 2008, Bloomberg estimated

\footnotetext{
Id.

Crocker, supra note 1.

Id.

Lorenzo, supra note 6; see also Lyons, supra note 3.
}

25 Kuwait Investment Authority Official Website, About Kuwait Investment Office in London, http://www.kia.gov.kw/En/KIO/About/Pages/default.aspx (last visited Oct. 9, 2010). While one of the first, the Kuwait Investment Authority may not be the first SWF. The Economist reports that the first SWF was established in the Gilbert Islands of Micronesia. The World's Most Expensive Club, ECONOMIST, May 24, 2007, available at http://www.economist.com/node/9230598?story_id=9230598.

26 Kuwait Investment, supra note 25.

27 Id.

28 Abu Dhabi Investment Authority Website, Mission, http://www.adia.ae/En/About/Mission.aspx (last visited Oct. 9, 2010).

29 Philip Whyte \& Katinka Barysch, What Should Europe Do About Sovereign Wealth Funds?, CTR. FOR EUR. REFORM BULL. (2007), available at http://www.cer.org.uk/articles/56_whyte_barysch.html. 
that the Abu Dhabi Investment Authority manages as much as $\$ 875$ billion.

Set up not long after ADIA, was GIC, "a global investment management company established in 1981 to manage Singapore's foreign reserves." $^{31}$ Also from Singapore is Temasek. ${ }^{32}$ Temasek Holdings was created from the idea that the fund would be able to better manage the government's funds and allow Singapore's Ministry of Finance to primarily focus on "its core role of policy making and government administration.",33 Norway, a petroleum-rich country, established its own SWF in 1996, "as a fiscal policy tool to support a long-term management of the petroleum revenues." 34 The Kuwait Investment Authority, ADIA, GIC, Temasek, and the Norwegian Government Pension Fund are five out of the largest seven SWFs. $^{35}$ The remaining two members of the largest seven SWFs derive from Russia and China.

\section{Recent SWF Additions - China and Russia}

Russia began creating its own sovereign wealth fund, called the Fund for National Well-Being, in 2008. ${ }^{37}$ At that time, like many Middle Eastern countries, four years of rising crude oil prices had been extremely beneficial to Russia." "The Fund for National Well-Being, with \$32 billion, is intended to buoy the pension system as the Russian population ages and the share of those working shrinks." ${ }^{39}$

The China Investment Corporation (CIC) was created in late September of $2007 .{ }^{40}$ "CIC was established on September 29, 2007, with the issuance of special bonds worth RMB 1.55 trillion by the Ministry of Fi-

\footnotetext{
30 William Mellor \& Le-Min Lim, China's Cash Offensive, BloOMBERG MARKETs, Apr. 2008, at 78.

31 GIC Website, About Us, http://www.gic.com.sg/about/overview.

32 See Temasek Holdings Website, Media Centre, Frequently Asked Questions, http://www.temasekholdings.com.sg/media_centre_faq.htm (last visited Oct. 9, 2010).

33 Id.

34 Norwegian Government Pension Fund Website, Fact Sheet, http://www.regjeringen.no/upload/ FIN/Statens\%20pensjonsfond/PFG_summary_march2010.pdf (last visited Oct. 9, 2010).

35 Heyward, supra note 12, at 19; see also Lyons, supra note 3, at 185 (stating that the largest seven sovereign wealth funds are: Abu Dhabi, GIC of Singapore, Norway, Kuwait, China, Russia and Temasek).

36 Heyward, supra note 12, at 19.

37 Andrew E. Kramer, Russia Creates $\$ 32$ Billion Fund for Foreign Investment, N.Y. TIMES, Feb. 1, 2008, at C2 ("Under a law passed last spring, the new fund can be invested in foreign stocks and bonds.").

38 Id.

39 Id.

40 China Investment Corporation Website, About Us-Overview, http://www.chinainv.cn/cicen/about_cic/aboutcic_overview.html (last visited Oct. 9, 2010).
} 
nance. These were, in turn, used to acquire approximately $\$ 200$ billion of China's foreign exchange reserves and formed the foundation of its registered capital.",41

Unlike the early SWF countries, China and Russia are geopolitical rivals to the West with huge amounts of investment capital. ${ }^{42}$ Discussion of the implications of the Chinese and Russian SWFs appear later in the comment. $^{43}$

\section{B. Sovereign Wealth Funds in the Marketplace}

\section{SWF Activity in the Marketplace from 2007-2008}

Estimates suggest the funds had as much as \$2.9 trillion to invest during this period, giving them expansive investment horizons. ${ }^{44}$ During 2007 and 2008, SWFs accounted for major investments in very well-known corporations. ${ }^{45}$ In the summer of 2007, China's SWF purchased $\$ 3$ billion of a "nonvoting stake in the Blackstone Group."46 Just less than five percent of Citigroup's voting stock, valued at $\$ 7.9$ billion, was purchased by the Abu Dhabi Investment Authority. ${ }^{47}$ Temasek Holdings, Singapore's SWF, acquired $\$ 4.4$ billion of new Merrill Lynch stock in December of $2007 .^{48}$ In January 2008, Merrill Lynch also sold " $\$ 6.6$ billion of mandatory convertible preferred stock to Korea Investment Corporation, Kuwait Investment Authority, and [a non-SWF third party], Japan's Mizuho Bank." ${ }^{49}$

In all, sovereign wealth funds' direct investments in U.S. financial firms between August 2007 and April 2008 reportedly amounted to more than $\$ 30$ billion, of which $\$ 17$ billion was invested in commercial banking organizations. . . . [M]ore than 90 percent of these funds

41 Id.

42 "China's SWF is projected to grow by $\$ 200$ billion per year, Russia's by $\$ 40$ billion. The emergence of these new funds is important because they originate from potential geopolitical rivals that are less likely to play by the West's rules." Whyte \& Barysch, supra note 29. To put the buying power of China's SWF in perspective a different way, "[w]ere China's fund so inclined, it could buy Ford, G.M., Volkswagen, and Honda, and still have a little money left over for ice cream." James Surowiecki, Sovereign Wealth World, NEW YORKER, Nov. 26, 2007, available at http://www.newyorker.com/talk/ financial/2007/11/26/071126ta talk surowiecki.

43 See infra Part II.C.

44 The Invasion of the Sovereign Wealth Funds, supra note 5.

45 Heyward, supra note 12, at 20.

46 Keith Bradsher \& Joseph Kahn, In China, a Stake in Blackstone Stirs Uncertainty, N.Y. TiMES, May 29, 2007, at C2.

47 Heyward, supra note 12, at 20.

48 Id.

$49 \quad I d$. 
emanated from the sovereign wealth funds of just four countries: the United Arab Emirates, Kuwait, Singapore, and China. ${ }^{50}$

At the time, with Wall Street and the U.S. economy on the decline, these investments were "trumpeted [by the treasury] as international votes of confidence. But those investments have been disastrous for the foreign purchase[rs] as Asian and Persian Gulf authorities have lost billions on Blackstone Group, Citigroup, Merrill Lynch, and other investments."

\section{SWFs in the Marketplace After the Boom in late 2008-2010}

The economic conditions of late 2008 and 2009 were vastly different than those of 2006 or 2007 . "Sovereign wealth funds [were] a beneficial source of capital for U.S. financial institutions;" however, like other investors, did not come through the financial crisis unscathed. ${ }^{52}$ At the beginning of 2009, analysts estimated that SWFs collectively incurred losses between eighteen and thirty percent in $2008 .^{53}$ Singapore's SWF, Temasek, provides an example in dollar terms, "Temasek’s assets had fallen from $\$ 134$ billion

50 Id.; see also Walker \& Chorazak, supra note 14, at 1 ("In 2007, sovereign wealth funds injected over $\$ 25$ billion into capital-starved American financial institutions. . . . One widely cited study projects that they [sovereign wealth funds] will have as much as $\$ 12$ trillion by $2015 . ")$.

51 Daniel Gross, Saving the People's Bank of China, Slate, Sept. 8, 2008, http://www.slate.com/id/2199564/; see also Daniel Gross, Fannie, Freddie, Folly, SLATE, July 11, 2008, http://www.slate.com/id/2195218.

[S]aviors were quickly turned into chumps. . . . [For] example, Citigroup sold interest-bearing convertible securities, which convert into Citi shares between 2010 and 2011 at prices ranging from $\$ 31.83$ to $\$ 37.24$ per share, to the Abu Dhabi Investment Authority. Since then, Citigroup's stock has fallen by more than half of its original value to less than $\$ 17$. Sovereign wealth funds that bought into offerings from companies like Merrill Lynch have suffered the same fate.

Id.

52 Rachelle Younglai, Sovereign Wealth Funds Not Harmful: U.S. Officials, REUTERS, Mar. 5, 2008, available at http://www.reuters.com/articlePrint?articleId=USN0563670420080305 (quoting Federal Reserve Board General Counsel Scott Alvarez).

53 Pamela Ann Smith, Sovereign Wealth Funds Reassess Their Strategies, MiddLE E. MAG., Jan. 2009 ("[C]ollectively [SWFs] may have recorded paper losses of between 18\% and 25\% last year."); see also Andrew England, Sovereign Wealth Funds Lose Their Gloss, FIN. TIMES, Jan. 28, 2009, available at http://www.ft.com/cms/s/0/9d0c9ff2-ed5b-11dd-88f3-0000779fd2ac.html ("Analysts suggest that they may have incurred losses of 25 per cent to 30 per cent."); see also Spencer Swartz, International Finance: Government Funds in Gulf Face 15\% Loss, WALL ST. J., Nov. 28, 2008, at C3 ("Seven sovereign-wealth funds in the oil rich Persian Gulf region are expected to lose $15 \%$ of their value this year due to the drop in global financial markets, Samba Financial Group said in a report Wednesday."); see also From Torrent to Trickle, ECONOMIST, Jan. 22, 2009, available at http://www.economist.com/node/12998177 (citing a paper by Brad Setser of the Council on Foreign Relations and Rachel Ziemba of RGE Monitor estimating that SWFs lost twenty-seven percent of their assets last year). 
at the end of [March 2008], to $\$ 84$ billion at the end of November [2008].,"54 Given that oil prices continued to fall, ${ }^{55}$ a major source of capital for SWFs, funds proceeded cautiously. ${ }^{56}$ The New York Times warned: "[d]on't expect Middle Eastern sovereign wealth funds to jump on the bailout bandwagon. Given the recent volatility in the stock markets, some large sovereign wealth funds have been hoarding cash." ${ }^{57}$ Similarly, in the January 22, 2009 edition, The Economist asked:

WHATEVER happened to sovereign-wealth funds? Eighteen months ago SWFs were destined to acquire swathes of Western companies for foreign governments, not all of which always passed the smell test. They then had a brief cameo as the saviours of Western banks, piling in where few other investors dared to tread. But lately things have gone quiet. That partly reflects the big losses that many funds are sitting on. But there is also a suspicion that the funds are a little passé; that their importance was as exaggerated as the merits of leveraged buy-outs or originate-to-distribute banking. ${ }^{58}$

After the marketplace saw SWFs take several major hits on investments made during the bailout, the buzz surrounding SWF investments certainly calmed. $^{59}$ Despite the tumultuous investments during the early days of the financial bailout, SWFs still had plenty of capital to invest and companies were well aware of this fact. In March 2009, SWFs were reported to have between $\$ 3.9^{60}$ and $\$ 3.22^{61}$ trillion under management. Furthermore, while SWFs acted more cautiously, well aware of their cash flow $^{62}$ and investment capabilities, many large companies still actively courted SWF investment. For example, "Brazil's Vale, the world's biggest

54 Chip Off the New Block, ECONOMIST, Feb. 12, 2009, available at http://www.economist.com/node/13110746.

55 Jack Healy \& Dave Jolly, Once Again, Stocks Slide in Last Hour of Trading, N.Y. TIMES, Nov. 18,2008 , at B4.

56 Id.

57 Landon Thomas Jr., Sovereign Funds Now Prefer Hoarding Cash to Rescuing U.S. Financial Firms, N.Y. TIMES, Oct. 14, 2008, at B7.

58 From Torrent to Trickle, ECONOMIST, Jan. 22, 2009, available at http://www.economist.com/ node/12998177.

59 Id.

60 Sovereign Wealth Funds Gain, WALL ST. J., Mar. 3, 2009, at C3.

61 Sovereign Wealth Funds Continue to Grow, Reach \$3.22 Tln - Study, WALl ST. J., Mar. 26, 2009, available at http://www.preqin.com/item/sovereign-wealth-funds-continue-to-grow-reach-3-22th-study/102/1277 (The $\$ 3.22$ trillion "dwarfs the $\$ 1.3$ trillion held by the private equity industry and could well be used to help fund private equity acquisitions while the credit markets remain frozen.").

62 "Today, cash is no longer king, cash is God, if you don't have cash flow . . . you won't be able to sell your project to investors." Vale Says Welcomes Sovereign Wealth Fund Investment, REUTERS, Mar. 23, 2009, http://www.reuters.com/article/idUSSP40515720090324 (quoting Fabio Barbaso, CFO at Vale). 
iron ore miner" sought SWF investment. ${ }^{63}$ Furthermore, many SWFs turned their gaze domestically and invested inward to support their home economies. Losses that came as a result of the global financial crisis sparked a debate ${ }^{64}$ among SWFs - whether they should take advantage of investments abroad or shift their investment focus to stabilizing their domestic markets.

In response to the financial crisis, SWFs began acting in their countries early in 2009. The Qatar Investment Authority announced its intent to "raise its stakes in local listed banks to between 10 and 20 percent to shore up their balance sheets." ${ }^{66}$ Also, in the Middle East, "[t]he Kuwait Investment Authority (KIA) [engaged in] steps to support that country's beleaguered stock market and [reportedly invested] up to KD1.5bn (\$5.2bn) as part of a government fund to prop up the bourse.,"67 "Faced with a worsening global economy, China Investment Corp. [adjusted] its investment plan ... [and] slowed its investments." ${ }^{, 68}$ The China Investment Corp. also turned its focus domestically and increased "its stakes in Industrial \& Commercial Bank of China Ltd. and China Construction Bank Corp. and

63 Id.

64 For example, “[w]ith the global credit squeeze, 'the average Kuwaiti or Abu Dhabian can't get a mortgage or a car loan.'. . 'They wonder why the funds are bailing out the Citigroups of this world."' Stanley Reed, Sovereign Wealth Funds Take a Hit, Bus. WK., Jan. 12, 2009, at 44. Also:

CIC invested $\$ 5$ billion in a U.S. money-market fund, the Reserve Primary Fund, that held $\$ 785$ million of Lehman Brothers Holding Inc. commercial paper and medium-term notes when the investment bank filed for bankruptcy-court protection in September. CIC said in October that it expected to recoup its investment because it requested the money be withdrawn shortly before the fund froze redemptions. CIC bought stakes in Blackstone Group LP in June 2007, while the fund was still being created, and in Morgan Stanley in December 2007. The values of these investments have dropped substantially, leading to strong public criticism at home.

Patricia Jiayi Ho, Crisis on Wall Street: China's Wealth Fund Says 'Cash is King', Wall St. J., Jan. 6, 2009, at C3. "Many [Chinese] believe CIC is squandering the nation's wealth with its forays into Western finance." Peter Stein \& Rick Carew, Deal Journal/Breaking Insight From WSJ.com, WaLL ST. J., Dec. 5, 2008, at C2.

65 England, supra note 53; see also Smith, supra note 53 ("[T] investment strategies as the global financial crisis and worsening economic climate continue to take a heavy toll on many emerging market economies. . . [M] [Mny SWFs are now suffering losses at a time when their own economies at home need closer attention.").

66 England, supra note 53.

67 Id.; see also Andrew Critchlow, World News: Big Mideast Funds Scale Back Investments-Last Year's Hot Investors at Davos Take Cautious Approach to West After Losses; Focus on Emerging Markets, WALl ST. J., Jan. 27, 2009 at A6 ("[T]he Kuwait Investment Authority pumped \$418 million into Gulf Bank, the sheikhdom's fourth-largest traded lender, after it suffered heavy derivatives-trading losses."). "With the global credit squeeze, 'the average Kuwaiti or Abu Dhabian can't get a mortgage or a car loan.' . . 'They wonder why the funds are bailing out the Citigroups of this world." Reed, supra note 64 .

68 Jiayi Ho, supra note 64. 
Bank of China." 69 Norway funded a NKR 20 billion fiscal stimulus package from its sovereign wealth fund. ${ }^{70}$ "Russia ... depleted their reserves to defend their currencies from capital outflows.",

In the first half of 2009, as a consequence of SWFs focusing on their domestic markets and faced with difficult economic conditions globally, SWF spending was only $\$ 11$ billion, marking its lowest point since 2004 . In the second half of 2009, SWF investment picked up, reaching a combined total of $\$ 50$ billion for the third and fourth quarters of $2009 .^{73}$ Also, despite a rollercoaster ride through the marketplace over the past two years, several SWFs that invested in troubled companies at the beginning of the financial crisis reaped large rewards in December 2009. ${ }^{74}$ Both Kuwait's and Singapore's SWFs reported gains, $\$ 1.1$ billion and $\$ 1.6$ billion, respectively, after cashing out stakes in banks that were obtained early in the financial crisis. ${ }^{75}$

Looking forward, the consensus is that SWFs will act more conservatively over the next few years, but will continue to invest abroad. ${ }^{76}$ For example, the China Investment Corp. has represented that most of their assets were invested as of 2009, so 2010 is mainly a year focused on managing, adjusting, and rebalancing the SWF's portfolio.

\section{State Influence Over SWFs Creates National Security and Economic Concern}

In the middle of what many deemed the financial crisis, some economists and analysts argued that "we should welcome [SWF] investments"; 78 however, only three years before the financial crisis, Congress had been the home of several highly publicized, controversial debates about foreign-

69 Rick Carew, Mr. Fang's Buys Stake in Bank of China, WALL St. J., Jan. 17, 2009, at B4.

70 Norway: Finance Outlook, ECONOMIST InTELLIGENCE Unit, Jan. 27, 2009.

71 From Torrent to Trickle, ECONOMIST, Jan. 22, 2009, available at http://www.economist.com.

72 Mina Kimes, Sovereign Wealth Funds on the Hunt, CNN MONEY, Dec. 23, 2009, http://money.cnn.com ("The funds collectively reported just 11 deals worth $\$ 11$ billion in the second quarter, the lowest amount since 2004, according to British consulting firm Monitor Group.”).

73 Steve Goldstein, Sovereign Wealth Funds Buying up More Foreign Assets: Study, MARKET WATCH, Mar. 1, 2010, http://blogs.marketwatch.com.

74 Eric Dash, Big Paydays For Rescuers in the Crisis, N.Y. TIMES, Dec. 7, 2009, at B1.

75 Id.

76 England, supra note 53.

77 Victoria Ruan, CIC Guarded on Greek Aid, WALL ST. J., Mar. 5, 2010, available at http://www.wsj.com.

78 Lorenzo, supra note 6 (quoting David Marchick of the Carlyle Group). For example, sovereign wealth funds' recent injections of capital into several OECD financial institutions were stabilizing because they came at a critical time when risk-taking capital was scarce and market sentiment was pessimistic. OECD, supra note 18 . 
owned companies making acquisitions in sensitive sectors. ${ }^{79}$ First, in the summer of 2005, Cnooc, an oil company with seventy percent Chinese government ownership, attempted to purchase Unocal, an American oil company. ${ }^{80}$ The Cnooc deal fell under political pressure as lawmakers voiced economic and political concerns mainly based on national security issues. $^{81}$ As roadblocks to the deal, the House and Senate actually passed amendments that "ordered the Energy Department to conduct a four-month review of the deal before reaching a decision." "82 Amidst the "broad tensions in the United States over economic security and economic competition with China," the Chinese Government and Cnooc officials withdrew from the deal. ${ }^{83}$

Then in early 2006, a "company controlled by the government of Dubai in the United Arab Emirates," Dubai Ports World, purchased management rights to terminals at five American ports from London-based Peninsular \& Oriental Steam Navigation Co. ${ }^{84}$ After the transaction concluded, under heavy pressure from Washington, Dubai Ports World agreed to sell its U.S. operations to a U.S. entity. ${ }^{85}$ In the case of Dubai World Ports, even though the United States Treasury Department approved the deal, lobby-

\section{Bradsher, supra note 46:}

The Chinese government is acquiring nearly 10 percent of an influential investment company [Blackstone] without a repeat of the fights that surrounded a bid two years ago by a state-owned oil company, Cnooc, for an American rival, Unocal, or last year's effort by DP World of Dubai to assume management of American port terminals.

Id.

80 David Barboza \& Andrew Ross Sorkin, Chinese Company Drops Bid to Buy U.S. Oil Concern, N.Y. TIMES, Aug. 3, 2005, at A1.

81 Edmund L. Andrews, Shouted Down, N.Y. Times, Aug. 3, 2005, at C1:

The political uproar began almost immediately. On June 30, the House passed two contradictory resolutions - one that demanded a "thorough review" of the potential dangers to national security, and a second that would have flatly prohibited the Treasury Department from recommending approval. Those did not become law, [but the order to the Energy Department did].

$82 \quad I d$.

83 Barboza \& Sorkin, supra note 80.

84 Greg Hitt \& Sarah Ellison, Abandon Ship: Dubai Firm Bows to Public Outcry; Media Sparked Firestorm As Bush Got Snagged In Bipartisan Criticism; Frist Takes an Early Stand, Wall St. J., Mar. 10, 2006, at A1.

85 Id.; see also Neil King Jr. \& Greg Hitt, Dubai Ports World Sells U.S. Assets; AIG Unit Buys Operations That Ignited Controversy As Democrats Plan Changes, WALL ST. J., Dec. 12, 2006, at A2:

Dubai Ports World sold the port contracts for an undisclosed sum to AIG Global Investment Group, a New York based asset management company with $\$ 683$ billion in assets but no experience in port operations. The new owner said it plans to run the ports of New York/New Jersey, Philadelphia, Baltimore, Miami, Tampa, and New Orleans at arms length and will make no changes in day-to-day operations. 
ists, ${ }^{86}$ media, ${ }^{87}$ and lawmakers ${ }^{88}$ alike framed the issue in national security terms.

While Cnooc and Dubai Ports World are not sovereign wealth funds, they are companies controlled or owned by foreign governments, so the political sensitivities they faced are indicative of those facing SWFs. ${ }^{89}$ The most obvious concern is that since not all SWFs come from democratic nations or countries that are known to always be friendly to the West, ${ }^{90}$ "[t]he fear is that these funds could be modern-day Trojan horses, with political, not economic or commercial considerations being the basis for investment decisions and, in turn, jeopardizing national security."

Gazprom, the Russian state-controlled energy company, serves as a good example of why policy makers are concerned about giving these funds too much of a stronghold over any sector of the economy. ${ }^{92}$ In 2006, "Gazprom . . . slapped its 400\%-plus natural gas price hike on Ukraine just as winter gained hold and Ukrainian President Yushchenko faced a financial crisis. . . . [Ukraine, at the time, was] [d] ependent on Russia for $30 \%$ of its natural gas." 93 While Russian officials argued that the move was strictly founded on economic reasons, the Ukrainian President and external parties certainly perceived the position to be in response to the new pro-western

86 Hitt \& Ellison, supra note 84:

In late January, a small Florida company began sowing the seeds of trouble in Congress. Eller \& Co., a Fort Lauderdale stevedoring firm that is a partner at the Port of Miami with P\&O, feared its business would be harmed by the DP World takeover. An Eller executive asked Joe Muldoon, a former drug-industry lobbyist, to work the halls of Capitol Hill. Mr. Muldoon came out of what he calls "semiretirement" to take the job, and quickly cloaked the issue in patriotic themes. "It's about foreign control over critical infrastructure - during wartime," he says.

87 Id. ("A company in the United Arab Emirates is poised to take over significant operations at six American ports as part of a corporate sale, leaving a country with ties to the Sept. 11 hijackers with influence over a maritime industry considered vulnerable to terrorism.").

88 Id. ("Perhaps the most critical decision to ride the wave was made by Senate Republican leader Bill Frist, who by coincidence was visiting a port just as the heat was rising and decided to speak out against the deal.").

89 See Barboza \& Sorkin, supra note 80; see also Hitt \& Ellison, supra note 84.

90 Whyte \& Barysch, supra note 29.

91 Walker \& Chorazak, supra note 14; see also, e.g., Ian Bremmer, Reasons to Be Gloomy, SLATE, Sept. 18, 2008, http://www.slate.com/id/2197115 ("The sixfold increase in oil prices since 2002 has empowered the governments of some oil- and gas-exporting states to use their newfound market leverage as a political weapon. Political leaders in Russia, Iran, Venezuela, and others already use their hydrocarbon wealth to pick political fights.").

92 See generally Rajon Menon \& Oles M. Smolansky, Russia's Thuggery Backfires, L.A. TIMES, Jan. 8, 2006, at M6.

93 Id. 
political course of Ukraine. ${ }^{94}$ Similar concerns are echoed by commentators over Chinese control of resources.

A more recent example of the cautionary approach espoused by Congress may be an example provided by former U.S. Secretary of the Treasury Henry Paulson. During his trip to the Beijing Summer Olympics, Paulson alleges that he learned of a plot by Russia to force a financial bailout of Fannie Mae and Freddie Mac. ${ }^{96}$ Paulson claims that Russia sought to reach an agreement with China to both sell large portions of their bond holdings in the U.S. mortgage-lending entities to force the U.S. to bail the countries out. ${ }^{97}$ Russia denies the incident, ${ }^{98}$ but the alleged plot illustrates the way foreign governments may seek to undermine the U.S. economy.

Three other concerns stemming from sovereign wealth funds are: intellectual property rights, reciprocity, and transparency. First, intellectual property concerns arise because "some countries may see this as a way to move up the value curve quickly, as they acquire intellectual property and access to research, design and development that it may take years to develop at home." 99 Also, a question arises, for example, if China were to acquire intellectual property via SWF investment, should they be allowed to "secure intellectual property rights overseas, at a time when it cannot guarantee to safeguard such rights for foreign firms in their market"? ${ }^{100}$

In an Annual Report made to Congress by the Committee on Foreign Investment in the United States, three key findings were made regarding technology and intellectual property:

1. "Overall, foreign firms are neither concentrating their investment solely in critical technology areas nor taking an increasingly dominant

94 Kim Murphy, Russia Starts Cutting Off Ukraine Gas; Putin's Offer to Delay a Sharp Rate Increase is Rejected by Officials in Kiev, Who Were Holding out for a Gradual Move to Market Prices, L.A. TIMES, Jan. 1, 2006, at A3 ("'Russia's firm position that Ukraine should buy gas at European prices is certainly a reaction to the new political course Ukraine is pursuing now,' Socialist Party parliament deputy Mikola Rudkovsky said in a telephone interview from Kiev, the Ukrainian capital.”).

95 "China has been a leading buyer of overseas mining assets through state-owned firms, but it hasn't always been welcomed by governments anxious about resource control or by investors wary of selling at the bottom or ceding influence to a major customer." Vale Says Welcomes, supra note 62.

96 Michael McKee \& Alex Nicholson, Paulson Says Russia Urged China to Dump Fannie, Freddie Bonds, Bus. WK., Jan. 29, 2010, http://www.businessweek.com.

97 Russian MinFin Says Did Not Suggest that China Sell Fannie Mae, Freddie Mac Bonds, INTERFAX: RUSSIA \& CIS BUS. \& FIN. NEWSWIRE, Feb. 2, 2010.

98 Id.

99 Lyons, supra note 3, at 15.

100 Id. 
position in the overall development or production of U.S. critical technologies."

2. "There is no credible evidence of a widespread coordinated strategy among foreign governments or corporations to acquire critical U.S. technologies through the use of foreign direct investment.",102

3. "Although there is no evidence of a widespread coordinated strategy to obtain U.S. critical technologies through foreign direct investment, there is significant evidence that foreign governments are involved in other efforts to acquire such technologies."103

The third finding is regarded as the Key Espionage Finding in the Annual Report. ${ }^{104}$ "Foreign government entities - including intelligence organizations and security services - have learned to capitalize on private-sector technology acquisitions." 105 Therefore, while the first two findings demonstrate that SWFs have not been a proven source of intellectual property theft as of yet, the third finding certainly substantiates the concerns over intellectual property.

Second, some countries have called for reciprocity. For example, "French President Nicolas Sarkozy has called for reciprocal openness to investments by EU countries." "106 If Country A opens itself to investment from Country B, then Country B should extend equal investment opportunities to Country A. Therefore, some commentators believe this may be a mechanism to free up restricted markets. ${ }^{107}$

101 Committee on Foreign Investment in the United States, Annual Report to Congress Public Version 30 (2008) [hereinafter COMMITTEE REPORT].

102 Id. at 32 .

103 Id. at 38 .

104 Id.

105 Id. The report provides:

Some governments have established quasi-official organizations, either in the United States or in their home countries, to facilitate contact with overseas scientists, engineers, and businessmen. These organizations enable foreign government officials to directly gauge the level of access that various foreign experts have, or may gain, to sensitive U.S. technology. The identified experts can be approached for sensitive information when they return to their home countries, thereby avoiding the need for meetings in the United States that could fall under the watchful eyes of the U.S. law enforcement community.

Id.

106 Crocker, supra note 1. In addition, The Economist quotes Sarkozy as promising "to protect innocent French managers from the 'extremely aggressive' sovereign funds." The Invasion of the Sovereign Wealth Funds, supra note 5.

107 Lyons, supra note 3, at 193 ("If the West accepts that Chinese firms can buy freely overseas using state reserves then this should lead to pressure for China to open its domestic markets further. And the same pressure should be applied to other countries with large state funds that invest overseas."). 
The third concern is transparency, a key buzzword surrounding the SWF conversation. ${ }^{108}$ Aside from Norway's Government Pension Fund, ${ }^{109}$ which "disclos[es] both its holdings and the investment objectives that they are intended to achieve," most of the others are clothed in secrecy. ${ }^{110}$ In addition, at least one commentator has suggested that increased transparency would curb human rights abuses:

Sovereign wealth funds operate mostly outside the purview of financial regulators. For this reason, they are almost a perfect vehicle for potentially corrupt leaders who wish to enrich themselves without facing international scrutiny. There is substantial evidence demonstrating that when income from state assets is channeled through a small group of individuals, the state's economy, institutions, and human rights practices suffer.

Although such secrecy gives rise to concern, to be fair, some countries may have remained secretive about their SWF investments for their own national security reasons. ${ }^{112}$ Smaller countries with very wealthy funds such as Kuwait and Abu Dhabi ${ }^{113}$ of the United Arab Emirates, historically, do not have the most hospitable neighbors between Iraq and Iran. ${ }^{114}$

Nevertheless, in 2008, there was a strong push for greater transparency to help quell some of the concerns that policy makers have about the underlying investment motives of SWFs. ${ }^{115}$ A series of events occurred that even-

108 Id.; see also Crocker, supra note 1.

109 Norwegian Government Pension Fund Website, http://www.regjeringen.no/upload/FIN/ Statens\%20pensjonsfond/PFG_summary_march2010.pdf (see the text under the "Transparency" section) (last visited Oct. 9, 2010).

110 Heyward, supra note 12, at 21 ("The lack of transparency gives free rein to the worst fears regarding the motives of SWF investors. ...").

111 Patrick J. Keenan, Financial Globalization and Human Rights, 46 COLUM. J. TRANSNAT'L L. 509, 509, 518-19 (2008); see also Bremmer, supra note 91 ("High prices allow even marginal energy exporters like Sudan and Burma to resist international pressure for political reform.”).

112 Heyward, supra note 12, at 21.

113 Khalifa bin Zayed Al Nahyan, NEwSwEEK, Dec. 20, 2008, http://www.newsweek.com/2008/12/ 19/25-khalifa-bin-zayed-al-nahyan.html ("[T] he ADIA is publicity-shy. According to a recent study by the Monitor Group, the ADIA has made only 16 public deals in the past eight years.").

114 U.S. Department of State, Background Note: United Arab Emirates, http://www.state.gov/r/pa/ ei/bgn/5444.htm (last visited Oct. 9, 2010).

115 See, e.g., Rachael Younglai, Sovereign Wealth Funds Need transparency: Schumer, REUTERS (Feb. 6, 2008), http://www.reuters.com/article/Regulation08/idUSN0630992820080206 ("Sen. Charles Schumer ... said he welcomed foreign investment but called for more transparency among governmentcontrolled funds riding to Wall Street's rescue."). See also The Economist, which framed the choice simply-"Shed light or take heat." The Invasion of the Sovereign Wealth Funds, supra note 5. Several Sovereign wealth funds have chosen to begin shedding light. Press Release, The Department of the Treasury, Treasury Reaches Agreement on Principles for Sovereign Wealth Fund Investment with Singapore and Abu Dhabi (Mar. 20, 2008) (on file with author) [hereinafter Press Release, The Department of the Treasury] 
tually led to the IMF taking action to establish best practices for SWFs, as well as the formation of an International Working Group (IWG) with representatives from SWFs, their controlling governments, and countries that are hosts to SWF investment. ${ }^{116}$ In March 2008, officials from the U.S. Treasury met with representatives from ADIA and GIC and their respective governments, Abu Dhabi and Singapore. ${ }^{117}$ Just before the meeting in Washington, EU leaders proposed five principles for working toward "a common approach to increase[] the transparency, predictability and accountability of sovereign wealth funds." "I18 In addition, the largest seven SWFs called "for the World Bank, IMF, and OECD to work on a code of best practices of sovereign wealth funds in such areas as institutional structure, risk management, transparency and accountability." "119 In April 2008, the IWG was established in Washington. ${ }^{120}$

\section{International Working Group Establishes Voluntary Principles}

In October 2008, the IWG published "a set of 24 voluntary principles ["Santiago Principles"] designed to ensure an open international investment environment.", 121

An IWG statement said the purpose of the Santiago Principles was to:

- Establish a transparent and sound governance structure that provides for adequate operational controls, risk management and accountability

- Ensure compliance with applicable regulatory and disclosure requirements in the countries in which Sovereign wealth funds invest

116 See infra text accompanying notes 117-20.

117 A joint press release statement was released outlining policy principles for Sovereign wealth funds that the IMF and OECD should consider in drafting their best practices guides. Press Release, The Department of the Treasury, supra note 115.

118 Press Release, European Commission, Commission makes proposals to European Council on sovereign wealth funds (Feb. 27, 2008):

The communication sets out five principles: commitment to an open investment environment both in the EU and elsewhere, including in third countries that operate SOVEREIGN WEALTH FUNDS; support of multilateral work, in international organizations such as the IMF and OECD; use of existing instruments at EU and Member State level; respect of EC Treaty obligations and international commitments, for example in the WTO framework; proportionality and transparency. Id.

119 Heyward, supra note 12, at 21 (citing Statement of G-7 Finance Ministers and Central Bank Governors, Oct. 19, 2007 available at www.ustreas.gov/press/releases/hp625.htm).

120 Id. at 21; see also Walker \& Chorazak, supra note 14, at 10 (The IWG "includes 25 member countries, most of which either have sovereign wealth funds or are recipients of their investments, as well as representatives from the OECD and the European Commission.").

121 Willison, supra note 10. 
- Ensure Sovereign wealth funds invest on the basis of economic and financial risk and return-related considerations, and

- Help maintain a stable global financial system and free flow of capital and investment[.] ${ }^{122}$

The Santiago Principles were clearly meant to respond to the concerns of the countries within which SWFs invest. ${ }^{123}$ Clearly, the drafters of Santiago Principles heard the cry for transparency. ${ }^{124}$ The term "publicly disclosed" appears at least nine times in the Principles. ${ }^{25}$ SWFs must publicly disclose:

[T]he key features of the sovereign wealth fund's legal basis and structure, as well as the legal relationship between the SWF and the other state bodies . . .; the policy purpose of the SWF . . ; policies, rules, procedures, or arrangements in relation to the sovereign wealth fund's general approach to funding, withdrawal, and spending operations . . .; the governance framework and objectives, as well as the manner in which the sovereign wealth fund's management is operationally independent from the owner . . ; relevant financial information regarding the SWF . . . to demonstrate its economic and financial orientation, so as to contribute to stability in international financial markets and enhance trust in recipient countries; a description of the investment policy of the SWF .. .; and, the sovereign wealth fund's investment decisions should aim to maximize risk-adjusted financial returns in a manner consistent with its investment policy, and based on economic and financial grounds. ${ }^{126}$

In addition to transparency, the Santiago Principles respond to other criticisms and concerns as well. ${ }^{127}$ For example, throughout congressional testimony a repeated maxim is that so long as SWFs are acting with the goal of "maximizing profits rather than advancing geopolitical agendas"

122 Id.

123 See Santiago Principles, supra note 10, at 1. For a description of concerns surrounding Sovereign wealth funds leading up to the drafting of the Santiago Principles, see Heyward, supra note 13, at 20-21; see also Lyons, supra note 4, at 17-37; Walker \& Chorazak, supra note 14, at 6-10.

124 See infra text accompanying notes 125-26.

125 See Santiago Principles, supra note 10, at 1, 2, 4, 16, 17, 18, 19, 21, 22.

126 Id. at 1, 2, 4, 16, 17, 18, 19, 21, 22.

127 For a description of concerns surrounding Sovereign wealth funds leading up to the drafting of the Santiago Principles, see Heyward, supra note 12, at 20-21; see also Walker \& Chorazak, supra note 14, at 6-10; Lyons, supra note 3, at 17-37. 
they will be beneficial. ${ }^{128}$ The Santiago Principles have adopted similar language:

The governing bodies should act in the best interests of the SWF . . ; [d] ealing with third parties for the purpose of the sovereign wealth fund's operational management should be based on economic and financial grounds . . .; and, the sovereign wealth fund's investment decisions should aim to maximize risk-adjusted financial returns in a manner consistent with its investment policy, and based on economic and financial grounds. ${ }^{129}$

Promoting transparency and economic-motivated behavior, the Santiago Principles are a step in the right direction; however, these principles are voluntary and leave SWFs to self-governance. Given the ongoing concern, at least one group has formed a website to monitor the conduct of SWFs. ${ }^{130}$ Unfortunately, monitoring does not always lead to compliance; however, this may be the best result possible for the meantime, because given that SWFs are extensions of sovereign countries, self-governance is likely to always be an issue, unless SWFs collectively agree to be regulated by an international body.

2. OECD Supplements Santiago Principles with Best Practices for Countries that Receive SWF Investment

The OECD devised a set of principles meant to complement the Santiago Principles. The OECD principles "are inward investment policy principles identified by the OECD, which reinforce the importance of countries' open investment commitments and are applicable to SWF investments."131

In response to a request by the G7 Finance Ministers, the OECD launched a project to deal with the issues surrounding sovereign wealth funds and the "rise of investment protectionism and to maintain open markets." "132 The project is ongoing and addresses Freedom of Investment and

128 Lorenzo, supra note 6. But cf. Aaron Lorenzo, Foreign Investment: Lawmakers Receive Warnings on Monitoring Sovereign Wealth Funds, 25 ITR 1338 (2008) (Luis Gutierrez, Chairman of the Subcommittee on Domestic and International Monetary Policy, Trade, and Technology stated "[b]y definition, these funds are extensions of the state and should always be viewed as maximizing their nation's strategic interests in addition to maximizing profit.").

129 Santiago Principles, supra note 10, at 8, 14, 19.

130 See, e.g., SWF Institute, http://www.swfinstitute.org/ (last visited Oct. 9, 2010).

131 Treasury's OpEn InVESTMENT InITIATIVE, U.S. DEP'T OF TREASURY (2008), available at http://www.treasury.gov/resource-center/international/foreign-investment/Documents/Open-Investmentbackground.pdf.

132 Letter from Angel Gurria, OECD Secretary-General, Letter Transmitting the Report of the OECD Investment Committee to G7 Finance Ministers (Apr. 4, 2008) (on file with author). 
National Security. ${ }^{133}$ The OECD has stated that they have mechanisms capable of creating "guidance for countries receiving investments from sovereign wealth funds." "134 As part of the project, the OECD released a report titled Sovereign Wealth Funds and Recipient Country Policies. ${ }^{135}$

In their report, the OECD first reminds governments of the current policies established to promote international investment. ${ }^{136}$ The first principle, non-discrimination, is that SWFs should be placed on equal footing with domestic investors. ${ }^{137}$ The second principle echoes that of the host countries themselves - transparency. ${ }^{138}$ The OECD wants to ensure that SWFs have full access to information regarding the regulations that need to be navigated to invest in a host country. ${ }^{139}$ This means that laws are codified and published; governments will give interested parties notice if there is a problem so they can change paths; when regulations are being considered, policy makers will consult with investors; "commerciallysensitive information provided by the investor should be protected"; and governments disclose on a regular basis investment policy decisions. ${ }^{140}$ The third principle the OECD pushes for is less restriction on investment to allow free movement of capital. This principle is referred to as progressive liberalisation. ${ }^{141}$ The fourth principle is largely tied to progressive liberalisation and that is "standstill," or in other words, that countries will not introduce any new regulation. ${ }^{142}$ Fifth, is the principle of unilateral liberalisation:

Members also commit to allowing all other members to benefit from the liberalisation measures they take and not to condition them on liberalisation measures taken by other countries. Avoidance of reciprocity is an important OECD policy tradition. The OECD instruments are based on the philosophy that liberalisation is beneficial to all, especially the country which undertakes the liberalisation. ${ }^{143}$

133 Id.

134 Id. ("These instruments call for fair treatment of investors. They commit adhering governments to the principles of transparency, non-discrimination, liberalization and standstill, and to build this fair treatment into their investment policies. They provide for 'peer review of adhering countries' observance of these commitments.").

135 OECD, supra note 18, at 2 ("The project is independent from, but complements efforts underway in the International Monetary Fund (IMF) to develop voluntary best practices for SWFs.").

136 Id. at 3.

137 Id.

138 Id.

139 Id.

140 Id. at 5 .

141 Id. at 3.

142 Id.

143 Id. 
The OECD recognizes in its report that national security is a legitimate concern. $^{144}$ In recognizing the concern though, the OECD cautions member countries to exercise their right conservatively, so that national security concerns do not become a country's "general escape clause from their commitments to open investment policies." "145 With regards to national security the OECD suggests that recipient countries should still aspire to non-discrimination; however, "[w] here such measures are deemed inadequate to protect national security, specific measures taken with respect to individual investments should be based on the specific circumstances of the individual investment which pose a risk to national security."146 Furthermore, the OECD pushes for regulatory proportionality: restrictions on investment, or conditions on transaction, should not be greater than needed to protect national security and they should be avoided when other existing measures are adequate and appropriate to address a national security concern. $^{147}$ Recipient countries are requested to identify the national security concern; "maintain investment restrictions [that are] narrowly focused on concerns related to national security;" if possible, tailor responses to remove the concerns to allow transactions to go through; and only use restrictive policies as a last resort. ${ }^{148}$

\section{The COMMITTEE ON ForEIGN INVESTMENT IN THE UNITED STATES}

Countries have responded differently to SWF investment. France, for instance, under the direction of President Nicolas Sarkozy, created its own SWF to combat foreign SWFs. Italian Foreign Minister Franco Frattini has expressed government opposition to SWFs "owning more than 5 percent of any Italian companies." 149 Meanwhile, Spain actively sought investment from SWFs in Spanish bonds during the financial crisis. ${ }^{150}$ German chancellor Angela Merkel, with an eye to the East, responded with legislation that allows the German government to scrutinize foreign investment that seeks to take a position of more than 25 percent in a domestic company. ${ }^{151}$

144 Id. at 4.

145 Id. ("The OECD investment instruments recognize the right of member countries to take actions they consider necessary to protect national security (Article 3 on Public Order and Security of the OECD Codes of Liberalisation of Capital Movements and Current Invisible Transactions).”).

146 Id. at 5.

147 Id.

148 Id.

149 Katrin Bennhold, Urging Europe to Stay European, N.Y. TiMES, Oct. 22, 2008, at B7.

150 Id.

151 Berin Moves to Block Takeovers by Wealth Funds, KuwAIT TIMES, Aug. 20, 2008, available at http://www.arabtimesonline.com/client/pagesdetails.asp?nid=21232\&ccid=12; see also Germany Finalises Draft Law on Sovereign Wealth Funds: Report, AGENCE FranCE-PresSE, Jun. 2, 2008, avail- 
Similar to the German regulation, U.S. legislation allows for review of any foreign investors if deemed necessary. ${ }^{152}$ The group responsible for conducting such reviews in the United States is the Committee on Foreign Investment. $^{153}$

\section{A. Background on CFIUS and FINSA}

CFIUS is the inter-agency committee chaired by the Department of the Treasury that reviews foreign acquisitions of U.S. companies for national security threats. $^{154}$ CFIUS is the evolutionary product of legislation that allows the executive branch of the U.S. government veto power over foreign investment if seen as a threat to U.S. national security.

The roots of CFIUS can be found in the Defense Production Act of 1950. ${ }^{156}$ The Act was passed to ensure that the United States would be able to meet its needs for "critical materials" during times of peace and war. ${ }^{157}$ As a response to the large amount of foreign investment (i.e., Japanese) in the United States in the 1980s, Congress passed the Exon-Florio Amendment to the Defense Production Act of $1950 .^{158}$

The Exon-Florio Amendment "authorizes the President to block nonU.S. acquisitions and mergers with U.S. business operations if they are determined to be a potential threat to U.S. security interests. The President can order divestment in the case of a concluded transaction that could threaten U.S. security interests." ${ }^{159}$ Parties that were concerned that their transaction might be subject to scrutiny under the Amendment could submit to a voluntary government screening process before the conclusion of the

able

http://docs.newsbank.com/s/InfoWeb/aggdocs/AWNB/121142531DDEA310/0D0CB4F6C367F64A.

152 See infra Part III.A.-D.

153 Id.

154 Committee on Foreign Investment in the United States, U.S. DEP'T OF TREASURY, available at http://www.ustreas.gov/offices/international-affairs/cfius/.

155 See generally Crocker, supra note 1.

156 See generally 50 U.S.C. $\S 2062$ (2006); for a description of the events that led up to the passage of the act see Deborah M. Mostaghel, Dubai Ports World Under Exon-Florio: A Threat to National Security or a Tempest in a Seaport?, 70 ALB. L. REV. 583, 584-92 (2007).

157 See 50 U.S.C. $\S 2062(a)(6)$ (2006).

158 Crocker, supra note 1, at 457; see also Hobart Rowen, Foreign Ownership is No Threat, WASH. PoST, Dec. 14, 1989, at A31 ("Few current issues [at that time were] fraught with as much emotion as foreign purchases of American assets, especially when the buyer is Japanese.").

159 Harry L. Clark \& Sanchitha Jayaram, Intensified International Trade and Security Policies Can Present Challenges for Corporate Transactions, 38 CORNELL INT'L L.J. 391, 394 (2005); see also Mandatory, If You Choose, WASH. PosT, Mar. 5, 2006, at B2 ("[T] 1988 Exon-Florio amendment to the Defense Production Act that Congress adopted . . . enable[s] the president to block any foreign acquisition of a U.S. company that might threaten national security. The amendment mandates . . . foreign investment that could impinge on national security be subject to a 45 -day review."). 
transaction. $^{160}$ CFIUS, structured somewhat differently at that time, was responsible for administering the process. ${ }^{161}$ After its enactment, up until the September 11th attacks, the Exon-Florio amendment remained relatively dormant, ${ }^{162}$ and very rarely were deals not approved. ${ }^{163}$ Generally, unless a "transaction directly implicated military activity" parties would not bother to gain approval from CFIUS. ${ }^{164}$ After 9/11, the Bush Administration began paying heavy attention to foreign entities making purchases in the United States.

For a long time, since President George H.W. Bush's administration, critics in Congress had felt the law was inadequate to properly deal with foreign investment in the United States, ${ }^{166}$ and that administrations had not made proper use of the existing law. ${ }^{167}$ Even as the Bush Administration increased its scrutiny of such transactions, Congress was not satisfied with the communication from the White House regarding the CFIUS review processes. $^{168}$ In late 2006, Dubai Ports World filed its notice with CFIUS that it intended "to acquire the U.S. port assets of the Peninsular and Oriental Steam Navigation Company Limited as a minor part of a global acquisition," and controversy erupted. ${ }^{169}$ The Dubai Ports World "transaction had actually cleared the CFIUS process before political furor caused the deal to

160 Clark \& Jayaram, supra note 159, at 394.

161 Id.

162 Id. at 394-95.

163 See, e.g., John Burgess, Reversal of Firm's Sale Revives National Security Debate, WASH. Post, Mar. 22, 1991, at B1 ("Since passage of a 1988 law aimed at tightening government control over foreign purchases of American companies, federal officials have reviewed close to 540 deals. Yesterday, their first and only reversal of one appeared near completion.").

164 Clark \& Jayaram, supra note 159, at 395.

165 Id :

For example, the Defense Department sought to block acquisition of a semiconductor lithography company, Silicon Valley Group ("SVG"), by the Dutch lithography company ASML. The parties ultimately obtained a clearance for the transaction, but it required a ruling by the President himself. ... The government also intensely scrutinized several acquisitions of telecommunications and Internet service companies. These have included Nippon Telegraph and Telephone's purchase of Verio, Vodafone's purchase of AirTouch, and Deutsche Telekom's purchase of VoiceStream.

166 John Burgess, Reversal of Firm's Sale Revives National Security Debate, WASH. Post, Mar. 22, 1991, at B1 ("The long delay has been cited by congressional critics who contend that the 1988 law, passed to reflect congressional concern over a wave of foreign investment that began in the 1980s, is not strong enough and that the White House's use of it has been inadequate.").

167 Id.; see also Mandatory, If You Choose, WASH. Post, Mar. 5, 2006, at B2 ("Excerpts from the Feb. 23 Senate Armed Services Committee hearing on the bid by Dubai Ports World of the United Arab Emirates to manage some U.S. ports.").

168 See generally Deborah E. Mostaghel, Dubai Ports World Under Exon-Florio: A Threat to National Security or a Tempest in a Seaport, 70 ALB. L. REV. 583 (2007).

169 Crocker, supra note 1, at 457. A year earlier, U.S. legislators had also "blocked an $\$ 18.5$ billion bid for U.S. oil company Unocal Corp. by China's third-biggest oil company, state controlled Cnooc Ltd., on national security grounds." Mellor \& Lim, supra note 30. 
unravel." ${ }^{170}$ Previous to this transaction, there had already been tension between the Executive and Legislative Branches over the CFIUS review process. ${ }^{171}$ Dubai Ports World, combined with the preexisting tension, spurred "preliminary Congressional hearings to lay the groundwork for legislation to reform the CFIUS process." " Significant reforms were made to CFIUS as a result increasing CFIUS' ability "to safeguard national security."

The Foreign Investment and National Security Act of 2007 (FINSA) ${ }^{174}$ "amends Section 721 of the Defense Production Act, which was enacted in 1988 to provide for national security reviews of foreign investments. ${ }^{175}$ Pre-FINSA, CFIUS implemented Section 721 solely per Executive Order 11858." ${ }^{176}$ The U.S. Treasury notes three significant effects FINSA had on CFIUS. ${ }^{17}$

First, "FINSA maintains the narrow scope and efficient timeline of CFIUS review process." ${ }^{178}$ Generally, the CFIUS review process may be

170 Cecil Hunt, Review of Foreign Acquisitions of U.S. Businesses: the CFIUS Process Under FINSA, A.L.I. - A.B.A. ConTINUING LEGAL EDUC., May 8-10, 2008.

171 Crocker, supra note 1, at 457.

172 Id.

173 CFIUS REFORM OVERVIEW, U.S. DEP'T OF TREASURY (2008), available at http://www.treasury.gov/resource-center/international/Pages/Committee-on-Foreign-Investment-inUS.aspx:

The U.S. Treasury Department cites five major elements of reform since 2006 to CFIUS:

1) To internal procedures ...;

2) [The] Foreign Investment and National Security Act of 2007 (FINSA) passed Congress with bipartisan and Administration support and became effective October 24, 2007. . . ;

3) Executive Order 11858[, which established CFIUS,] of May 7, 1975, was amended by EO 13456 on January 23, 2008. . . ;

4) Final revised regulations were made public on November 14, 2008, after considering all public comments received proposed regulations that were issued April 21. . .;

5) Guidance will be published soon in the Federal Register on the types of transactions that CFIUS has reviewed and that presented national security considerations.

174 Foreign Investment and National Security Act of 2007, Pub. L. No. 110-49, 121 Stat. 246 (2007); see also Regulations Pertaining to Mergers, Acquisitions, and Takeovers by Foreign Persons, 73 Fed. Reg. 70,702 (Nov. 21, 2008).

175 Regulations Pertaining to Mergers, Acquisitions, and Takeovers by Foreign Persons, 73 Fed. Reg. 70,702 (Nov. 21, 2008) ("Section 721 authorizes the President to review mergers, acquisitions, and takeovers by or with any foreign person which could result in foreign control of any person engaged in interstate commerce in the United States.").

176 See Foreign Investment and National Security Act of 2007, 121 Stat. 246 (2007); CFIUS REForm: The Foreign InVESTMENT \& NATIONAL SECURity ACT OF 2007 (FINSA), U.S. DEP'T OF TREASURY (2008), available at http://www.treasury.gov/resource-center/international/foreigninvestment/Documents/Summary-FINSA.pdf [hereinafter CFIUS REFORM: FINSA].

177 Id.

$178 I d$. 
concluded within thirty days, a maximum of seventy-five days. ${ }^{179}$ In cases where he must, the President has fifteen days to act.

Second, FINSA has added new members to CFIUS. ${ }^{181}$ The Committee now includes the Secretary of Energy. ${ }^{182}$ Also, while neither the Director of National Intelligence nor the Labor Secretary participates in policy decisions, they advise CFIUS with analysis on national security issues and U.S. employment law, respectively. ${ }^{183}$

\section{Third, the Act "[i]ncreases senior-level accountability within
CFIUS." 184}

Treasury, as CFIUS chair, must designate, as appropriate, an agency or agencies with lead responsibility for each covered transaction. . . . [In addition,] at no lower than the Assistant Secretary level, Treasury and the lead agency must certify to Congress that CFIUS had "no unresolved national security concerns" in any review it concludes. ${ }^{185}$

17931 C.F.R. $\$ 800.501$ (2009); CFIUS REFORM: FINSA, supra note 176 (“CFIUS must conclude a review in 30 days and an investigation, if needed, in a subsequent 45 days."); see also Guidance Concerning the National Security Review Conducted by the Committee on Foreign Investment in the United States, 73 Fed. Reg. 74,567, 74,570 (Dec. 8, 2008):

[I]t is important that, at the time of filing a voluntary notice, parties provide CFIUS with the information needed for its review, including regarding the parties' products, services, and business operations, and the transaction itself. [Other information that should be included is] a listing of certain contracts with the U.S. Government, products that the parties produce or sell, the foreign person's plans with respect to the U.S. business, and the parties and individuals involved with the transaction.

For a more detailed description of information that should be included when filing the voluntary notice see 31 C.F.R. $\S 800.402$ (2009) as well as, http:/www.ustreas.gov/offices/internationalaffairs/cfius/, which suggests information that should be included in the voluntary notification, but may not be necessarily set forth in the Federal Regulations.

18050 U.S.C. $\$ 2170(d)(2)$ (2006); CFIUS REFORM: FINSA, supra note 176 ("In the rare case where CFIUS requests his decision, including on whether to prohibit or suspend a transaction, the President has 15 days to act.").

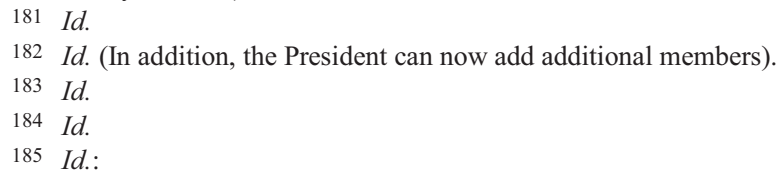

Other additions and changes made by FINSA: [1.] Mitigation agreements or conditions must be based on a "risk-based analysis"[; 2.] CFIUS [is required] to monitor and enforce compliance with mitigation measures and to track withdrawn notices. Allows for imposition of civil penalties[; 3.] CFIUS [may] reopen a review if the parties made a material omission or misstatement to CFIUS, or if the parties intentionally and materially breach a mitigation agreement. Before reopening, CFIUS must agree no other remedy is sufficient[; 4.] Filers must certify that filings are accurate, complete, and comply with the law[; 5.] Imposes on Congress, with regard to briefings from CFIUS, the same confidentiality rules that bind CFIUS with regard to all information provided by filers. 
In addition to FINSA, Executive Order 13456 made additional reforms to CFIUS. $^{186}$ Executive Order 13456 also expands membership on the CFIUS board ${ }^{187}$ (even more than FINSA), further refines the triggering mechanisms for CFIUS review, ${ }^{188}$ and imposes additional analytical and procedural duties on CFIUS agencies.

With all the additions that were made to CFIUS by FINSA and the amended Executive Order, it is worth noting what was not changed:

Specifically, it does not include a requirement that CFIUS breach confidentiality by notifying Congress of pending transactions, it does not incorporate "economic security" criteria, it does not authorize Congress to force an investigation or override presidential approval of particular transactions, it does not require notification of CFIUS reviews to state governors and it does not remove the Department of the Treasury from the chairmanship of CFIUS - all proposals that Congress had under consideration. Of these, the most important is that FINSA maintains CFIUS confidentiality. ${ }^{190}$

186 See Exec. Order No. 13456, 3 C.F.R. Exec. Order 13456, (2008).

187 Id: see also CFIUS REFORM: AMENDMENT OF EXECUTIVE ORDER 11858 ON JANUARY 23, 2008, DEP'T OF TREASURY (2008), available at http://www.treasury.gov/resourcecenter/international/foreign-investment/Documents/Summary-EO11858-Amend.pdf [hereinafter CFIUS REFORM: AMENDMENT].

The Executive Order adds the U.S. Trade Representative and Director of the Office of Science and Technology Policy to the Board as well as "the heads of the Office of Management and Budget, Council of Economic Advisers, and National Economic Council, and of the National Security Council and Homeland Security Council staff are added to observe, participate in, and, as approId. priate, report to the President on CFIUS's activities.

188 See Exec. Order No. 13456, 3 C.F.R. Exec. Order 13456, (2008); see also CFIUS REFORM: AMENDMENT, supra note 187.

Defines the Treasury's duties vis-à-vis lead agencies and other members, including acting as the point of contact with outside parties, designating lead agencies for any part of a case, and reviewing material action proposed by a lead agency in order to ensure coordination within CFIUS and provide CFIUS's direction. . . . Ensures that all CFIUS members are able to participate fully in every CFIUS review, specifying that any CFIUS member can trigger an investigation if it believes a transaction under review threatens to impair national security and that threat has not been mitigated. . . . Provides mechanism for CFIUS to request that the President decide whether a transaction should be suspended or prohibited - which only he may do - where a transaction threatens to impair the national security of the U.S. and other laws, besides Section 721 and the International Id.

Emergency Economic Powers Act, are inadequate or inappropriate to address that threat

189 See Exec. Order No. 13456, 3 C.F.R. Exec. Order 13456 (2008); see also CFIUS REFORM: AMENDMENT, supra note 187 ("Risk mitigation provisions must be justified by a written analysis of the national security risk posed by a transaction, and CFIUS must agree that they are justified.").

190 Crocker, supra note 1, at 465. 
Confidentiality is crucial because while CFIUS has authority to begin reviews, the Committee encourages voluntary submission to the review process. Maintaining confidentiality gives corporations comfort to share the requisite materials with the Committee without fear that corporate secrets will become public.

The timing of the process and what constitutes a covered transaction that must be submitted to CFIUS review is discussed in parts $\mathrm{B}$ and $\mathrm{C}$ below.

\section{B. The CFIUS Review Process}

The review process is initiated by sending written notification to the Committee of a proposed covered transaction. ${ }^{191}$ The Committee then will review the transaction "to determine the effects of the transaction on the national security of the United States" section C. ${ }^{193}$ A covered transaction "means any transaction . . . by or with any foreign person, which could result in control of a U.S. business by a foreign person." 194 CFIUS does not issue advisory opinions, so any voluntary notification to the committee will result in a review. ${ }^{195}$

The initial review to be conducted must be completed within thirty days. "CFIUS concludes action on the vast majority of transactions within this initial 30-day review period." 197 If, during the first thirty days, a determination is made that the "transaction threatens to impair the national security of the United States . . . the transaction is a foreign governmentcontrolled transaction, or the transaction would result in control of any critical infrastructure" by a foreign person, then the Committee will have fortyfive days to conduct an investigation. ${ }^{198}$ Then, after the conclusion of the forty-five-day period, CFIUS may conclude action "only if it has determined that there are no unresolved national security concerns. That determination must be certified to Congress after CFIUS concludes action."199

191 See supra text accompanying notes 178-217.

19250 U.S.C. app. $\S 2170($ b)(1)(A) (2008).

193 See supra text accompanying notes 178-217.

19431 C.F.R. $\$ 800.207$ (2009).

195 Guidance Concerning the National Security Review Conducted by the Committee on Foreign Investment in the United States, 73 Fed. Reg. 74,567, 74,572 (Dec. 8, 2008).

19650 U.S.C. app. $§ 2170($ b)(1)(E).

197 Guidance Concerning the National Security Review Conducted by the Committee on Foreign Investment in the United States, 73 Fed. Reg. at 74,568.

19850 U.S.C. app. $§ 2170($ b)(2)(B).

199 Guidance Concerning the National Security Review Conducted by the Committee on Foreign Investment in the United States, 73 Fed. Reg. at 74,568. 
To resolve national security concerns, CFIUS is empowered to institute mitigation measures. $^{200}$

"Only the President has the authority to suspend or prohibit a covered transaction." 201 Presidential action may be required if (1) prohibition or suspension is recommended by the Committee; (2) the Committee members cannot reach a decision whether to make a recommendation to the President; or (3) the Committee requests that the President make a decision. ${ }^{202}$ In situations where the President is required to act, he must do so within 15 days of the conclusion of the investigation. ${ }^{203}$

\section{National Security and Factors Considered During CFIUS Review}

CFIUS was created to consider national security effects of foreign investment; however, the statutes do not define "national security,"204 and since September 11, 2001 the U.S. government has construed the term more broadly. $^{205}$ However, FINSA did make clear that "national security" does include "critical infrastructure" which includes "major energy assets."206

Under the CFIUS review process set forth by FINSA, the factors that are considered, taking into consideration the requirements of national security, are:

(1) domestic production needed for projected national defense requirements;

(2) the capability and capacity of domestic industries to meet national defense requirements ... ;

(3) the control of domestic industries and commercial activity by foreign citizens as it affects the capability and capacity of the United States to meet the requirements of national security;

(4) the potential effects of the proposed or pending transaction on sales of military goods, equipment, or technology to any country . . .;

(5) the potential effects of the proposed or pending transaction on United States international technological leadership in areas affecting United States national security;

200 See infra pt. D. Mitigation Measures Under CFIUS Review.

201 Guidance Concerning the National Security Review Conducted by the Committee on Foreign Investment in the United States, 73 Fed. Reg. at 74,569.

20231 C.F.R. $\S 800.506$ (b) (2009).

20350 U.S.C. app. $\$ 2170(\mathrm{~d})(2)$.

204 See 50 U.S.C. $\$ \S 2061-2170$.

205 See generally Crocker, supra note 1.

206 Id. at 465. 
(6) the potential national security-related effects on United States critical infrastructure, including major energy assets;

(7) the potential national security-related effects on United States critical technologies;

(8) whether the covered transaction is a foreign government-controlled transaction ....;

(9) as appropriate ... (A) the adherence of the subject country to nonproliferation control regimes, including treaties and multilateral supply guidelines . . ; (B) the relationship of such country with the United States, specifically on its record on cooperating in counterterrorism efforts . . .; and (C) the potential for transshipment or diversion of technologies with military applications, including an analysis of national export control laws and regulations;

(10) the long-term projection of United States requirements for sources of energy and other critical resources and material; and

(11) such other factors as the President or the Committee may determine to be appropriate, generally or in connection with a specific review or investigation. ${ }^{20}$

The Department of the Treasury has provided written guidance as to the transactions CFIUS has reviewed and those that have been thought to present a national security consideration. ${ }^{208}$ The Treasury's written guidance describes two divisions of transactions that CFIUS has reviewed because of their security considerations: (1) those that are a concern because of "the nature of the U.S. business over which foreign control is being acquired, and (2) [those that are a concern because of] the nature of the foreign person that acquires control over a business."209

Note that simply because "a transaction presents a national security consideration, [it] does not necessarily mean that it poses a national security risk." 210 In order for there to be a risk present, there must be a threat and

20750 U.S.C. app. $§ 2170(f)(1)-(11)$.

208 Guidance Concerning the National Security Review Conducted by the Committee on Foreign Investment in the United States, 73 Fed. Reg. at 74,570-72.

209 Id. at 74570; see also Regulations Pertaining to Mergers, Acquisitions, and Takeovers by Foreign Persons, 73 Fed. Reg. 70,702 (Nov. 21, 2008) (describing two additional times when CFIUS may review transactions: (1) "where the lead agency recommends, and CFIUS concurs, that an investigation be undertaken; [and] . . . [2] where a member of CFIUS advises the chairperson that it believes that the transaction threatens to impair the national security.").

210 Guidance Concerning the National Security Review Conducted by the Committee on Foreign Investment in the United States, 73 Fed. Reg. at 74,571. 
"vulnerability in U.S. national security.",211 Very often any national security considerations that CFIUS may recognize are resolved by laws other than section 721 , eliminating the vulnerability. ${ }^{212}$

Concerning the transactions that are reviewed because of the nature of the U.S. business, the first businesses that CFIUS calls attention to are those that provide "products and services . . . to agencies of the U.S. Government and state and local authorities." panies that one would expect the government to clearly be concerned with for national security reasons: "businesses in the defense, security, and national security-related law enforcement sectors, and covered such industry segments as weapons and munitions manufacturing, aerospace, and radar systems." ${ }^{214}$ In addition, CFIUS has reviewed transactions that involve companies that supply goods and services directly to U.S. Government agencies (e.g., "information technology . .. . telecommunications, energy, natural resources, industrial products, and a range of goods and services"). ${ }^{215}$

Businesses that are not directly connected to government agencies are also reviewed. ${ }^{216}$ Businesses in the energy sector, ${ }^{217}$ transportation, $^{218}$ and financial sector ${ }^{219}$ are examples of businesses not related to government agencies that may require review. The Treasury's guidance then points out transactions that are related to critical infrastructure, but does not give any examples of these transactions, only that they will be decided on a case-bycase basis. ${ }^{220}$ Other business industries that the guidance names specifically as subject to review are those that "have both commercial and military applications" (i.e., businesses engaged in the production of semiconductors, "cryptography, data protection, internet security, and network intrusion detection").

211 Id.

212 Id.

213 Id. at 74570.

214 Id.

215 Id.

216 Id.

217 Id. ("For example, . . . businesses in the energy sector at various stages of the value chain: the exploitation of natural resources, the transportation of these resources (e.g., by pipeline), the conversion of these resources to power, and the provision of power to U.S. Government and civilian customers.").

218 Id. ("[I]ncluding maritime shipping and port terminal operations and aviation maintenance, repair, and overhaul.").

219 Id. (Specifically, "U.S. businesses that could significantly and directly affect the U.S. financial system.").

220 Id.

221 Id. at 74570-71 ("More generally, . . businesses that are engaged in the research and development, production, or sale of technology, goods, software, or services that are subject to U.S. export controls."). 
The Treasury's guidance offers a list of factors that may be considered in transactions that are under review as a result of the identity of the foreign person making the investment. ${ }^{222}$ CFIUS will consider "the record of the country of the investor with regard to nonproliferation and other national security-related matters."223 CFIUS will also take into consideration the intentions of the foreign person in regards to the operation of the business after it acquires ownership. ${ }^{224}$ Specifically, if the foreign person "plans to terminate contracts between the U.S. business and U.S. Government agencies for goods and services relevant to national security," this may trigger review. $^{225}$

CFIUS will also review transactions that are "foreign governmentcontrolled transaction[s]." ${ }^{, 226}$ A foreign government-controlled transaction is "any covered transaction that could result in control of a U.S. business by a foreign government or a person controlled by or acting on behalf of a foreign government."227 "Foreign government-controlled transactions may include transactions by . . . sovereign wealth funds." 228 However, "[t]he fact that a transaction [involves a sovereign wealth fund] does not, in itself, mean that it poses national security risk." 229 Control is an important issue in transactions by SWFs. ${ }^{230}$ Specifically, CFIUS will consider if the SWF has "the capability to use its control of a U.S. business to take action to impair U.S. national security and whether the [SWF] may seek to do so."231 Section 800.204(a) of the Federal Regulations defines control:

222 Id. at $74571-72$.

223 Id. at 74571.

224 Id.

225 Id.

$226 I d$.

22731 C.F.R. $\S 800.214$ (2009); see also 31 C.F.R. $§ 800.207$ (2009) (“[C]overed transaction means any transaction that is proposed or pending after August 23, 1988, by or with any foreign person, which could result in control of a U.S. business by a foreign person.").

228 Guidance Concerning the National Security Review Conducted by the Committee on Foreign Investment in the United States, 73 Fed. Reg. at 74,571.

229 Id. ("Foreign government-controlled transactions may [also] include . . . [those involving] foreign government agencies, state-owned enterprises, [and] government pension funds.”).

230 See 31 C.F.R. $\S \S 800.204,800.207,800.214,800.216,800.302$; Guidance Concerning the National Security Review Conducted by the Committee on Foreign Investment in the United States, 73 Fed. Reg. at 74,571; see also Regulations Pertaining to Mergers, Acquisitions, and Takeovers by Foreign Persons, 73 Fed. Reg. 70,702, 70,704 (Nov. 21, 2008) ("[T]he concept of control appears in several different places throughout the regulations, both in those sections that define the nature of the acquirer and those that define the transaction itself."').

231 Guidance Concerning the National Security Review Conducted by the Committee on Foreign Investment in the United States, 73 Fed. Reg. at 74,571; see also Regulations Pertaining to Mergers, Acquisitions, and Takeovers by Foreign Persons, 73 Fed. Reg. at 70,704 ("This focus on control suggests a fundamental congressional judgment that national security risks are potentially highest in trans- 
The term control means the power, direct or indirect, whether or not exercised, through the ownership of a majority or a dominant minority of the total outstanding voting interest in an entity, board representation, proxy voting, a special share, contractual arrangements, formal or informal arrangements to act in concert, or other means, to determine, direct, or decide important matters affecting an entity; in particular, but without limitation, to determine, direct, take, reach, or cause decisions regarding the following matters, or any other similarly important matters affecting an entity.

The definition does not define control in terms of ownership percentage or number of board seats. ${ }^{232}$ Rather the definition looks at control more broadly, including a "foreign person's ability to determine, direct, or decide important matters affecting an entity." $" 233$ An acquisition that will result in less than control as defined by $\S 800.204$ will not be subject to the review. ${ }^{234}$ Examples of transactions that may or may not be covered are given in 31 C.F.R. $\S \S 800.301,800.302$. In determining whether a transaction is covered based on control, the Committee considers, inter alia, who will hold the power to elect directors and appoint primary officers, ${ }^{235}$ and who will control the majority of a business's assets. ${ }^{236}$ Transactions that are not covered include stock splits that do not result in a change in control, ${ }^{237}$ and "transactions that result in a foreign person holding ten percent or less of the outstanding voting interest in a U.S. business, . . . but only if the transaction is solely for the purpose of passive investment.",238

\section{Mitigation Measures Under CFIUS Review}

Where CFIUS finds a threat to national security, the Committee may negotiate, impose, or enforce any condition necessary to mitigate threats to U.S. national security. ${ }^{239}$ Mitigation efforts include: "periodic reporting . . .

actions that involve the acquisition by a foreign person of control of an entity operating in the United States.").

23231 C.F.R. $\S 800.204$ (a) (2009).

233 Regulations Pertaining to Mergers, Acquisitions, and Takeovers by Foreign Persons, 73 Fed. Reg. at 70,704 .

234 See, 31 C.F.R. $\S 800.302$ (2009), for examples of transactions that are not covered.

23531 C.F.R. $\S 800.301(\mathrm{a})$.

23631 C.F.R. $\$ 800.301(\mathrm{c})$.

23731 C.F.R. $\$ 800.302$ (a).

23831 C.F.R. $\$ 800.302($ b)

23950 U.S.C. app. $§ 2170(1)(1)(A)$; see also COMMITTEE REPORT, supra note 101, at 15 ("The Committee has adopted procedures to evaluate and ensure that parties to a covered transaction remain in compliance with any risk mitigation measure entered into with CFIUS agencies, whether through a mitigation agreement, assurances, or other conditions."). 
by the companies; on-site compliance reviews . . . ; third-party audits when provided for by the terms of the mitigation agreement; and investigations and remedial actions if anomalies or breaches are discovered.",240

To put into perspective how often mitigation measures are undertaken, from 1997, "when CFIUS first negotiated a mitigation measure in the context of a transaction notified under section 721, [through 2008], CFIUS agencies . . . entered into a total of fifty-one mitigation agreements with private parties." 241

CFIUS agencies entered into fourteen mitigation agreements in 2007 . $^{242}$ "The agreements involved transactions in the following industries: basic manufacturing; energy; operations services for the aviation and maritime industries; and information technology, both hardware and software." ${ }^{243}$ In 2008 and 2009, CFIUS agencies entered into seven mitigation agreements. $^{244}$

Mitigation measures take various forms "ranging from national security agreements, which are generally contracts that seek to address a number of specific risks, to letters of assurance, which are simpler documents appropriate for less complex cases." 245 Eleven of the fourteen mitigation measures taken in 2007 were letters of assurance. ${ }^{246}$ The letters specify the measures that must be taken to mitigate national security concerns. ${ }^{247}$ The remaining three mitigation measures were in the form of national security agreements. ${ }^{248}$

In the event that a party does not comply with a mitigation agreement, CFIUS may impose civil penalties. ${ }^{249}$ The way a SWF may avoid CFIUS review altogether is discussed in section E below.

\section{E. Steps that May Be Taken by SWFs to Avoid CFIUS Review}

The consensus among policy makers and commentators appears to be that, so long as sovereign wealth funds avoid sensitive areas and taking

240 COMMITTEE REPORT, supra note 101, at 16. CFIUS agencies have hired new staff, designed tracking systems, and instituted new procedures to maximize the effectiveness of compliance monitoring. $I d$.

241 Id. at 15.

242 Id.

243 Id.

244 Committee on Foreign InVEStMent in the United States, ANNUAL Report to Congress 14 (2010) (for calendar year 2009).

245 COMMITTEE REPORT, supra note 101, at 15.

$246 I d$.

247 Id.

248 Id.

24931 C.F.R. $\S 800.801$ (c) (“A mitigation agreement . . . may include a provision providing for liquidated or actual damages for breaches of the agreement by parties to the transaction."). 
controlling shares in companies, no review will be triggered. ${ }^{250}$ "Pursuant to $\S 800.302$ (b), a foreign person does not control an entity if it satisfies a two-pronged test: (1) it holds ten percent or less of the voting interest in the entity, and (2) its interest is held solely for the purpose of passive investment." ${ }^{251}$ Passive investment is defined by 31 C.F.R. $§ 800.223$ (2009):

Ownership interests are held or acquired solely for the purpose of passive investment if the person holding or acquiring such interests does not plan or intend to exercise control, does not possess or develop any purpose other than passive investment, and does not take any action inconsistent with holding or acquiring such interests solely for the purpose of passive investment.

Structuring the transaction so that a local subsidiary has control over a U.S. business will not suffice to avoid review. ${ }^{252}$ In making their investments, SWFs should be careful, because certain minority protections are enumerated that may or may not trigger review. ${ }^{253}$ For example, the power to prevent the sale of substantially all the assets of a business or voluntary filing of bankruptcy will not trigger a review. ${ }^{254}$

Also, when reviewing SWF transactions CFIUS will consider:

The extent to which the basic investment management policies of the investor require investment decisions to be based solely on commercial grounds; the degree to which, in practice, the investor's management and investment decisions are exercised independently from the controlling government, including whether governance structures are in place to ensure independence; the degree of transparency and disclosure of the purpose; investment objectives, institutional arrangements, and financial information of the investor; and the degree to

250 See Rachelle Younglai, Sovereign wealth funds not harmful: U.S. officials, REUTERS, Mar. 5, 2008, available at http://www.reuters.com/articlePrint?articleId=USN0563670420080305 (quoting Federal Reserve Board General Counsel Scott Alvarez) ("[S]overeign wealth funds, like many other investments . . . have structured their investments so as not to trigger the threshold for review and approval . . . and have designed their investment to be passive.").

251 See 31 C.F.R. § 800.302(b) (2009); see also Regulations Pertaining to Mergers, Acquisitions, and Takeovers by Foreign Persons, 73 Fed. Reg. 70,702, 70,705 (Nov. 21, 2008).

252 Regulations Pertaining to Mergers, Acquisitions, and Takeovers by Foreign Persons, 73 Fed. Reg. at 70,705 ("[A] person that has the power to determine important matters of an entity does not avoid having control of that entity by voting the shares of a wholly-owned subsidiary that, in turn, votes the shares of the entity, or by acting through another intermediary or agent.").

253 See 31 C.F.R. $\S 800.204(d)$.

254 Regulations Pertaining to Mergers, Acquisitions, and Takeovers by Foreign Persons, 73 Fed. Reg. 70,702, 70,718 (Nov. 21, 2008). 
which the investor complies with applicable regulatory and disclosure requirements of the countries in which they invest. ${ }^{255}$

Therefore, to avoid review, SWFs should structure transactions to obtain less than 10 percent of a company as a passive investor. In doing so, create a business structure that acts independent of any government body in a transparent manner to achieve economic goals. Thus, being cognizant of all the factors CFIUS will consider to determine if a transaction is covered for review. Following the goals set forth by the Santiago Principles and the OECD will also help to avoid CFIUS review.

\section{CONCLUSION}

As this article reaches publication, the global economy continues to struggle and most countries continue to seek out methods to stimulate their economies. SWFs are a viable source of capital infusion for such troubled economies; however, they do create the concerns for host countries discussed in Section II.C above.

In the United States, amidst a rising air of desperation flowing from the strained economy, there has been a continual debate over the need for, and breadth of, regulation of financial markets and investment vehicles. Since its reformation, following the Dubai Ports World scandal, CFIUS appears to be the appropriate method for regulating SWFs in the United States by striking an appropriate balance between the need for regulation to secure the country and the need for confidentiality to encourage investment.

SWFs certainly seem to have appeared in far fewer headlines in 2010 than in the previous several years. Take care, however, not to write SWFs completely out of the dialogue of financial reform and regulation as merely

255 Guidance Concerning the National Security Review Conducted by the Committee on Foreign Investment in the United States, 73 Fed. Reg. 74,567, 74,571 (Dec. 8, 2008); Regulations Pertaining to Mergers, Acquisitions, and Takeovers by Foreign Persons, 73 Fed. Reg. 70,702, 70,708-09 (Nov. 21, 2008):

Commentators suggested that, in considering whether a transaction is foreign governmentcontrolled, the regulations should treat certain types of entities owned by foreign governments or that have a "government background" as not foreign government-controlled - for example, if they operate on a purely commercial and market-driven basis. ... [However], [t]he statute makes clear that transactions are "foreign government-controlled transactions" if they could result in the control of any person engaged in interstate commerce in the United States by a foreign government or an entity controlled by or acting on behalf of a foreign government, regardless of whether the transaction has a purely commercial and market-driven basis. . . . [When considering national security concerns however, CFIUS will take into consideration however, CFIUS will take into consideration] whether a foreign government-controlled entity operates on a purely commercial and market-driven basis. ... 
a settled issue. As long as SWFs exist as investment vehicles for foreign governments, protectionist sentiment will spark debate, and politicians and economists alike will discuss the security issues as well as the benefits and risks that arise from SWFs participating in the marketplace. 